\title{
Grammar video lessons to foster independent learners in the English as a foreign language classroom.
}

\section{Video lecciones de gramática para fomentar estudiantes independientes en el aula de inglés como lengua extranjera.}

Martha Lucia Lara Freire ${ }^{1}$, Gloria Isabel Escudero Orozco ${ }^{2}$, Blanca Narcisa Fuertes López ${ }^{3}$, Wilson Gonzalo Rojas Yumisaca 4 .

\section{Recibido: 20-04-2019 / Revisado: 25-05-2019 /Aceptado: 24-06-2019/ Publicado: 15-07-2019}

\begin{abstract}
.
DOI: https://doi.org/10.33262/cienciadigital.v3i3.1.689

For this study, the researcher recorded eight grammar video lessons based on the contents studied in Level Fourth in the English Center at Escuela Superior Politécnica de Chimborazo. These videos became both, a valuable tool to foster independent learning and a strategy to flip the traditional classroom, which allowed additional time to work on practical activities in the classroom, considering that the theory was taken outside the classroom. The instrument applied in this research were initial survey, satisfaction survey, pre-test, and post-test. The initial survey and the pre-test demonstrated the necessity students had to consolidate their knowledge regarding grammar and apply those contents into a real life context. Once the study ended, the students concluded that the grammar video lessons were effective and useful to achieve independence in learning the English grammar rules. Students who were part of the intervention reached a level of autonomous learning which influenced markedly in the
\end{abstract}

\footnotetext{
${ }^{1}$ Escuela Superior Politécnica de Chimborazo, Facultad de Salud Pública. Riobamba, Ecuador. mlaraf@espoch.edu.ec

${ }^{2}$ Escuela Superior Politécnica de Chimborazo, Facultad de Ciencias Pecuarias. Riobamba, Ecuador. gloria.escudero@espoch.edu.ec

${ }^{3}$ Universidad Nacional de Chimborazo, Facultad de Ciencias de la Salud. Riobamba, Ecuador. bfuertes@unach.edu.ec

${ }^{4}$ Escuela Superior Politécnica de Chimborazo, Facultad de Gestión del Transporte. Riobamba, Ecuador. wilson.rojas@espoch.edu.ec
} 
students grades as showed in the interpretation and analysis of the results. Additionally, students felt motivated because they had less "homework." Thus, it was concluded that the grammar video lessons foster independent learning.

Keywords: Independent Learning, Grammar Video Lessons, Flipped Classroom.

\section{Resumen.}

Para el presente trabajo, el investigador elaboró ocho lecciones de gramática en video, basadas en los contenidos estudiados en el Nivel Cuatro del Centro de Idiomas, de la Escuela Superior Politécnica de Chimborazo, estos videos consistieron una valiosa herramienta para fomentar el aprendizaje autónomo y una estrategia para cambiar el aula tradicional, dedicando más tiempo de la clase a la ejecución de actividades prácticas, puesto que la teoría gramatical se trasladó fuera del aula. Los instrumentos utilizados fueron: encuesta inicial, encuesta de satisfacción, pre-test y post-test. La encuesta inicial y el pre-test mostraron la necesidad de los estudiantes por consolidar sus conocimientos de gramática y tener la habilidad de aplicarlos en situaciones de la vida real. Al finalizar la investigación los estudiantes concluyeron que las lecciones de gramática en video fueron efectivas y útiles para lograr independencia en el aprendizaje de reglas gramaticales del idioma Inglés. El nivel de aprendizaje autónomo que los estudiantes alcanzaron influyó notablemente en las calificaciones de los estudiantes que fueron parte de la intervención pedagógica, lo que se comprobó en el análisis e interpretación de resultados. Adicionalmente los estudiantes se sintieron motivados puesto que los "deberes" disminuyeron. Se concluye por tanto que el uso de lecciones gramaticales en video promueve el aprendizaje autónomo.

Palabras claves: Aprendizaje Autónomo, Lecciones de Gramática en Video, Clase Invertida.

\section{Introduction}

Nizar Matar a professor of An-Najah National University states that students like to be spooned fed with easy to digest educational "capsules" in a similar way to "fast food" (Nizar, 2015). Based on this statement, this paper analyzes the facts that made the researchers propose this investigation on video grammar lessons to foster independent learners. It also describes the theories that scientifically support the proposal and discusses the results from 
an objective and real point of view comparing them with results of other studies also applying the same variables. Furthermore, this presentation creates awareness not only about the need students have to become independent learners (Zhen, 2014), but also the urgency of teacher's commitment to push students toward that independence (Hammond, 2015). Finally, it seeks to answer the following research question: Does the implementation of the flipped classroom model through grammar video lessons as homework train independent learners?

This study acquired a high level of importance due to the problems to be solved and the results that can be generalized and used by other professors in any other educational background. For instance, the major problems at the beginning of the semester were that students were not engaged with the learning-teaching process and had not developed the ability to create their own knowledge and critical thinking. Additionally, most of students under intervention were not autonomous learners and they did not perceive the role of the teacher as a mere facilitator of the knowledge (Ellis, 2004). According to the researchers and other faculty's point of view, even teachers do not realize the responsibility they must have to give students the necessary tools for them to become active participants in the learning process (Karen Murphy, 2016). The fact that classroom climate affects the student' ability to learn independently was also considered (Alpha Omega Academy, 2012). Therefore, proving the hypothesis, which helped upright a solution to this problem, implied to look deeper on student's perceptions of how knowledge is acquired, the roles they were willing to take in order to satisfy their needs and what results of the intervention they would apply along their learning process.

After working with different kind of activities in the classroom, it was observed that the majority of students were visual learners. Not to mention that, nowadays, young people prefer technology to printed material. Therefore, the general objective was to create grammar video lessons of the grammar contents studied in English Level 4 at Escuela Superior Politécnica de Chimborazo as instruments to promote self-study and as a strategy to diminish the in-class theory time making a way to take that acquired knowledge into practice. The specific objectives of this study were to learn grammar in a non-traditional, more fun way by using technology, to combine virtual education with face-to face activities, to provide more opportunities for students to practice grammar contents during the class time and to guide 
students in the use of the grammar video lessons at home as a technique which fosters selfstudy. The achievement of these objectives helped us reach a better comprehension of the generalizations discussed in this article.

The first variable is the so-called independent variable, which deals with video grammar lessons with focus on the flipped classroom model and the second variable, known as dependent variable has to do with independency, specifically to develop the necessary cognitive skills required for independent learning.

Flipped classroom was born in 2007, the founders are Jonathan Bergman and Aaron Sams, both science teachers. As many teachers, John and Aaron realized that they were not taking full advantage of the face-to-face time with their students and that when they sent homework, they were not physically there to guide their students; all those situations contributed to the Flipped Classroom model creation. The concept of flipped class is this: which was traditionally done in class is now done at home, and which was traditionally done as homework is now completed in class (Sams \& Bergmann, 2012).

The founders of this model started to record the theory or lecture on videos and podcasts for their students to have the opportunity to watch them as many times as they needed, at their own pace, and in the comfort of their home (Chen Hsieh, 2016).

Several studies dealing with the same variables refer to technology as the main tool to work with the flipping approach (Han, 2015)

On one hand, grammar video lessons, which are recorded materials carried out by the class tutor with content based on the syllabus and on student's needs, have to be designed with specific features such as an adequate length, i.e. not too short or too long. It needs to have the singularity to catch student's attention, so that they and even other people around them get involved in the teaching-learning process. Due to this fact, the teacher became as reachable as being in the student's pocket. Students could turn on, mute, rewind or repeat the class at will (Young, 2017). Seeing a video of the content class must feel like if the teacher were teaching one to one; something that it is hard to achieve in a public school setting. 
On the other hand, authors refer to independent learners as a student with "the ability to take charge of one's learning" (Carl, 2016) and it is necessary to comprehend that circumstances and learning style play a very important role, as it does age and maturity (Alpha Omega Academy, 2012). When a student becomes an independent learner, he or she exhibits features such as curiosity, persistence comprehension with little or no instruction, critical thinking, accountability, self-examination, and self-motivation and as the top effect students are capable to choose their own study strategies, which is remarkable because not very often teachers realize how a student learns, neither has the time or disposition to design tasks specifically directed to one or other student. That is why teachers who pretend to help their students become independent learners should design homework as positive experiences with clear objectives and instructions, and as varied as possible. Tasks to be done at home, have then to match the level of proficiency with focus on production (Harvey \& Ckie-Wolfe, 2007). Lastly, providing effective feedback, that is, timely and specific (Escudero, 2016) will positively contribute to this independency.

In order to contribute to this paper, it is necessary to remark some results from other researchers, for instance, the paper "Successfully flipping the ESL classroom for learner autonomy" written by Yu Jung Han (Han, 2015) points out that autonomy was gained once the teacher created more opportunities for meaning-focused output and this was clearly identified when students submitted more works than teacher expected. Also, when the tutor planned them to look for resources that would help them learn independently, they, enthusiastically look for learning activities that worked out for them and that were very valid to share with others. The second study "Using the flipped classroom to enhance EFL learning" remarks that doing independent activities, not only notably increased student's motivation and active participation, but also significantly improved their knowledge of the content managed in class (Hsieh, Wu, \& Marek, 2016). Finally, the study "A Case Study on a Flipped Classroom in an EFL Content Course" suggests that it is necessary to make students realize that they are able to learn by themselves, become active participants of the class, and help others to learn.

The context in which the research was applied, the findings on students' survey and tests, and all the above stated considerations made of this study a tool to take EFL students and 
teachers to the next level, which is switching from traditional to flipped classroom (Lara, 2016).

According to Boulhuis and Voeten (2001), cited by Meyer, promoting independent learning requires a new role for teachers, a flip from traditional transmission of information to a process-oriented teaching, which ensures that students are actively involved in the learning process (Meyer, 2010).

The striking angle about this study is to see how everything fits, considering that not only the teacher's, but also the students' role changes. The dependent learner is a passive recipient of knowledge, who accepts the teacher as the expert in the learning process; whereas the independent learner is active in directing and regulating his or her own learning and becomes a learning expert (Meyer, 2010).

Furthermore, the ability to blend information processed and information processing without teacher intervention as setting the independent apart from the dependent learner (Meyer, 2010).

\section{Methodology}

The background of this proposal draws on EFL students enrolled in Level Fourth at a public undergraduate school. The equivalence of this level is A2 of the Common European Framework of Reference for Languages. Students come to class 4 hours a week and taking the English program is mandatory for all student's majors. Before graduating, students should be proficient at a B1 level. The sample was thirty students; in this group, $50 \%$ of students were male and $50 \%$ female. They had different cultural backgrounds and different levels of knowledge; some of them had not taken English classes continuously, the majority of them were not familiar with the proposed method; therefore, they agreed on the importance of using technology in the classroom and the necessity of becoming independent learners and be active part in the learning process. The course content was designed with a grammarbased syllabus (Nunan, 2002) and the tutor had to create her own material and implement her own methodology.

Previous conducting the study, the researcher did observation, the most relevant findings were gathered in a logbook, some of the notes were taken from students and other from 
teachers opinions, the main objective of this previous-research stage was to identify the problem. Once the problem (students' poor development of cognitive independent skills) was identified, a problem-tree was structured in order to establish the cause and effect as well as the possible solution for this problem.

The research design was quasi-experimental because the study was empirical and aimed at analyzing the impact of the intervention on the target group, the experimental and control group were not chosen randomly; besides the research was developed in natural educational scenarios. In order to prevent bias, the control group, which was not exposed to the intervention, belonged to a different teacher, not the researcher; whereas, the experimental group was intervened by the researcher. The experimental and control groups had 30 students from different cultural and educational background; for that reason, an initial survey and a pre-test were applied at the beginning of the intervention. It was clear that students had not developed the necessary cognitive skills required for independent learning; therefore, the researcher chose the flip classroom as the method to solve this problem.

This idea sounded very innovative, challenging, and motivating that the researcher reordered eight grammar video lessons for the English Fourth Students. The videos are based on the grammar contents planned in the syllabus: Wishes in Present, Past and Future; Zero Conditional, First Conditional, Second Conditional, Third Conditional and Adjective clauses. The series is divided into two categories: lecture and exercises; the purpose was for students to understand the grammar rules first by watching the grammar video lessons created by the teacher and then practice what they learnt in class with the teacher's guide.

Since, it was important that students had the videos available all the time; first, the researcher opened an account on YouTube to upload the videos and the videos were also included in the Virtual Classroom students had for the English class.

Regarding the evaluation and monitoring, the teacher used the WSQ chart, which students had to fill in and discuss it with the teacher and the class the next day. In this chart, students had to write information about what they Watch and include the name of the video. Then, students needed to Summarize the new content they learned and finally, they wrote Questions they still had about the topic. Once the teacher read the questions, 10 minutes from the class 
were taken for effective feedback. In this time, the teacher reinforced the information or knowledge students already had and then started with the practice.

As the flipped class model was implemented the main focus was on practice, the researcher created worksheets to work with the students in class, the emphasis was on letting students be active part of their learning and feel the necessity to learn by themselves.

The researcher used the YouTube Teacher Channel and a Virtual Learning Environment to have the videos available for students to watch them at their own pace. In addition, for recording the videos, the researcher had the support of students and teachers of the Graphic Design School. This School has implemented a recording studio; this was a great contribution to the video quality.

The videos were also recorded into a $\mathrm{CD}$, so students did not have to wait until they had internet access to watch the videos. $90 \%$ of the sample had internet access i.e. only one student in the experimental group had to work offline (Lara, 2016). Nevertheless, the reality in rural areas or Elementary School students could be different; in this case, students can take a great advantage of the CDs.

Concerning the statistics, the T-test also known as Student's T-Test was applied because it compares two averages and establishes the difference from each other; besides it verifies the significance of the differences to make sure that they did not happen by chance (Stephanie, 2018). This statistic was applied to tabulate and analyze the results of the pre-test and posttest, both were given online by using the Virtual Classroom created for this purpose. The test had 31 questions, which were focused on the grammar contents assigned for Level Fourth: Wishes, Conditionals, and Adjective Clauses. In addition to the inferential statistic, the descriptive one was also considered to analyze the results from the initial and satisfaction surveys taken by the experimental and the control group students.

\section{Results}

The first stage of the research was to identify the problem by elaborating a problem tree, which showed three relevant findings: low level of intrinsic motivation to learn English, insufficient use of technology as part of the English classroom, and the necessity to look for 
new methods or strategies to teach grammar. In this stage, the researchers also took advantage of the data gathered through observation and the notes in the logbook.

The next step was to apply the initial survey to have a clearer idea of the chosen groups (experimental and control) needs. Several interesting facts were found and they are detailed in the charts below.

Figure 1: Percentage of students who had heard about flipped classroom

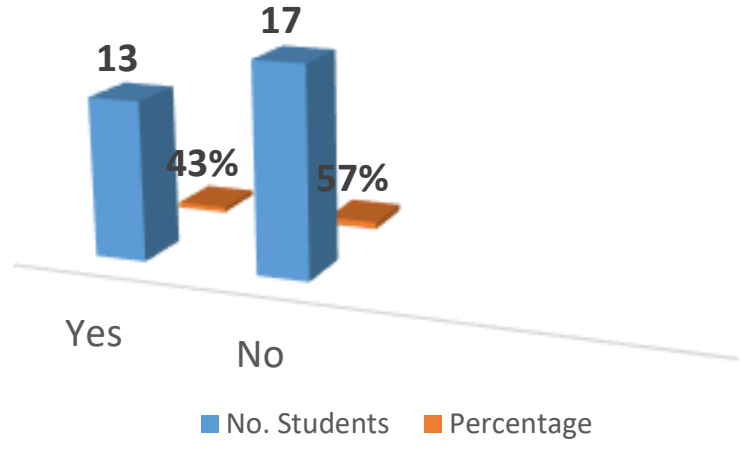

Fuente: Escuela Superior Politécnica de Chimborazo

Figure 2: Percentage of students whose teachers have used grammar video lessons

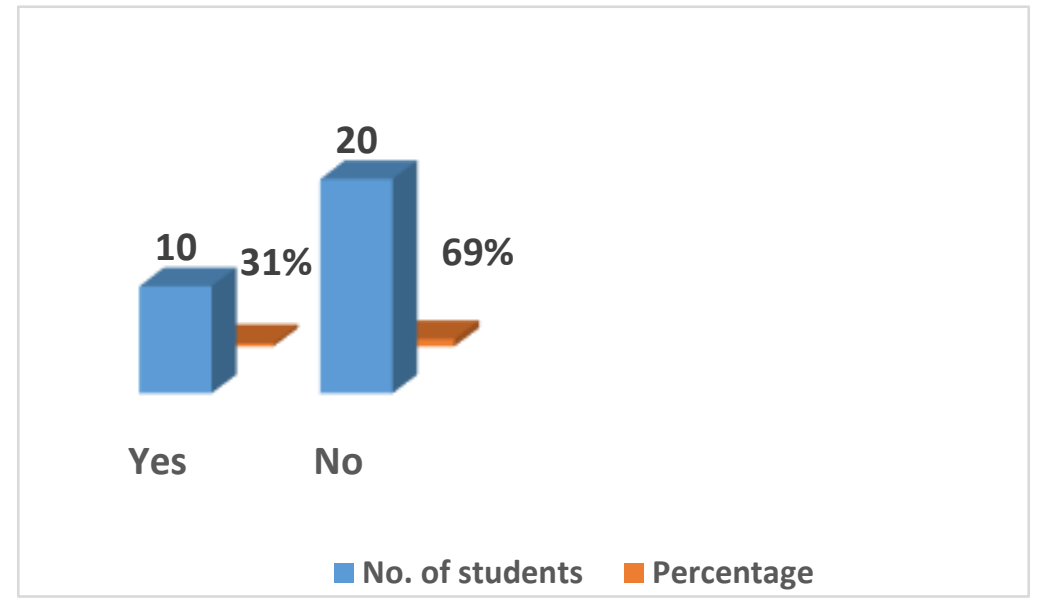

Fuente: Escuela Superior Politécnica de Chimborazo 
Figure 3: Percentage of students who think video lessons could be helpful to learn grammar

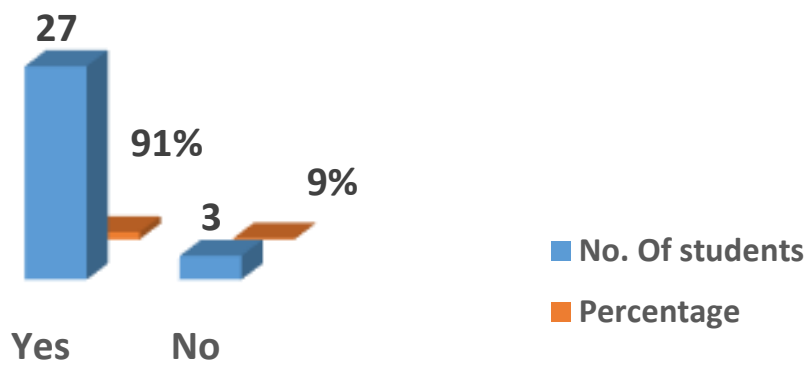

Fuente: Escuela Superior Politécnica de Chimborazo

Figure 4: Percentage of students who think that classes should be directed to production more than to content

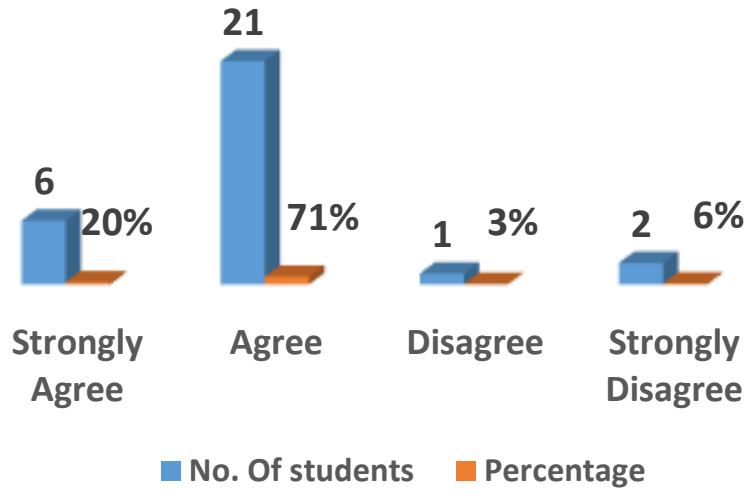

Fuente: Escuela Superior Politécnica de Chimborazo

Figure 5: Percentage of students who think that one of the teacher's goal should be to foster independent learners

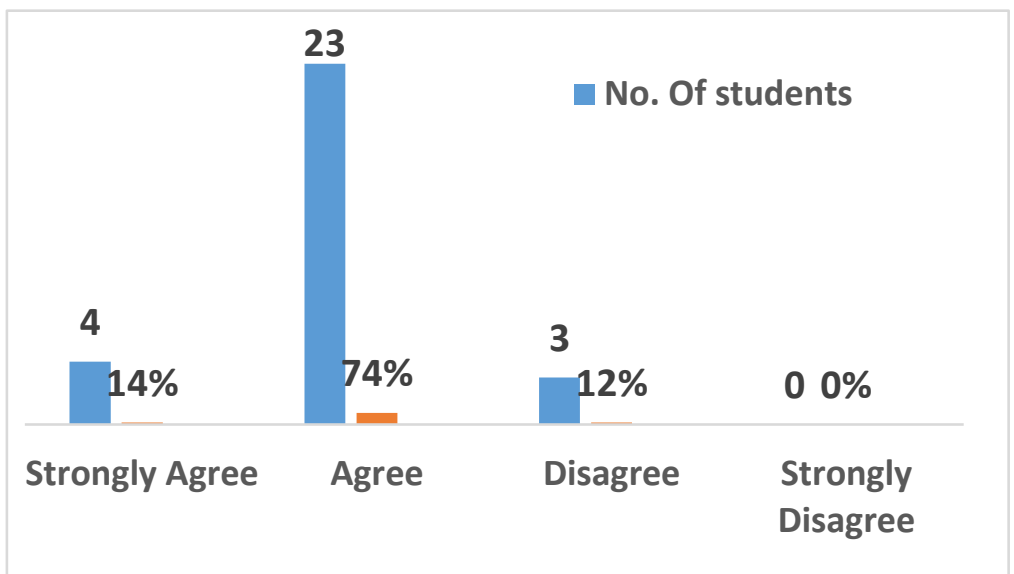

Fuente: Escuela Superior Politécnica de Chimborazo 
In the initial survey, which students completed on line (google drive), the most relevant findings regarding the dependent and independent variables were the following: $57 \%$ of students mentioned that they had not heard about flipped classroom, $69 \%$ of students stated that their teachers had not used video lessons to teach grammar, $91 \%$ of students considered that grammar video lessons could be helpful to learn grammar, $74 \%$ of students agreed that the English classes should be directed to production more than content, and $71 \%$ of students were awarded of the importance to foster independency in the learning process.

After applying the post-test, the pre-test and post-test results, both from experimental groups and control group were tabulated; these results are detailed in the following table.

Table 1: Pre-test and Post-test results

\begin{tabular}{|c|c|c|c|c|c|c|c|c|c|}
\hline \multicolumn{5}{|c|}{ Pre-Test } & \multicolumn{5}{|c|}{ Post-Test } \\
\hline $\begin{array}{c}\text { № } \\
\text { students }\end{array}$ & \multicolumn{2}{|c|}{ Control Group } & \multicolumn{2}{|c|}{ Experimental Group } & \multirow{3}{*}{$\begin{array}{c}\text { № } \\
\text { students } \\
30\end{array}$} & \multicolumn{2}{|c|}{ Control Group } & \multicolumn{2}{|c|}{ Experimental Group } \\
\hline stúcitos & $\begin{array}{l}\text { Mean } \\
\text { Value }\end{array}$ & Percentage & $\begin{array}{l}\text { Mean } \\
\text { Value }\end{array}$ & Percentage & & $\begin{array}{l}\text { Mean } \\
\text { Value }\end{array}$ & Percentage & $\begin{array}{l}\text { Mean } \\
\text { Value }\end{array}$ & Percentage \\
\hline & 1,48 & $14,80 \%$ & 1 & $10,00 \%$ & & 2,68 & $26,80 \%$ & 7 & $70,00 \%$ \\
\hline
\end{tabular}

Note: This table shows the average of grammar knowledge improvement.

The average for the control group in the pre-test was 1,48; whereas, in the experimental group, it was 1,00; these results suggested that the level of the experimental group was lower than the control one. In the post-test the control group average was 2, 68 and the experimental group average was 7,00. These results showed that the experimental group students' knowledge about grammar improved significantly since there is a difference of 6 points when comparing the pre-test and post-test results.

Finally, the results of the satisfaction survey, which was applied at the end of the intervention, were analyzed. This instrument results are detailed below. 
Table 2: Level of satisfaction

\begin{tabular}{|c|c|c|c|c|c|c|c|}
\hline & 1 & 2 & 3 & 4 & 5 & DA & Total \\
\hline & 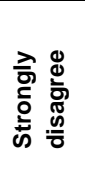 & 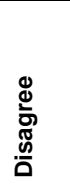 & 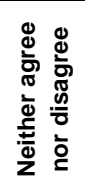 & 这 & 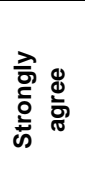 & 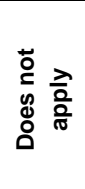 & \\
\hline $\begin{array}{l}\text { Using video lessons to introduce new grammar } \\
\text { content is an effective technique? }\end{array}$ & 0 & 0 & 1 & 18 & 7 & 4 & 30 \\
\hline $\begin{array}{l}\text { How useful were the video lessons to learn } \\
\text { grammar? }\end{array}$ & 0 & 0 & 3 & 11 & 12 & 4 & 30 \\
\hline How would you rate the content of the videos? & 0 & 0 & 1 & 8 & 17 & 4 & 30 \\
\hline $\begin{array}{l}\text { How would you rate the quality of the videos (audio, } \\
\text { image)? }\end{array}$ & 0 & 0 & 1 & 6 & 19 & 4 & 30 \\
\hline $\begin{array}{l}\text { The video lessons were enough to understand and } \\
\text { apply the grammar contents. }\end{array}$ & 0 & 1 & 2 & 18 & 5 & 4 & 30 \\
\hline $\begin{array}{l}\text { How useful was the WSQ chart for understanding the } \\
\text { grammar content in the video lessons? }\end{array}$ & 0 & 1 & 4 & 16 & 5 & 4 & 30 \\
\hline $\begin{array}{l}\text { Based on your experience would you recommend the } \\
\text { use of the grammar video lessons in the English } \\
\text { classroom? }\end{array}$ & 0 & 0 & 1 & 13 & 12 & 4 & 30 \\
\hline $\begin{array}{l}\text { To what extend did the grammar video lessons } \\
\text { contribute to the development of the activities in the } \\
\text { class in an autonomous way? }\end{array}$ & 0 & 0 & 3 & 17 & 6 & 4 & 30 \\
\hline $\begin{array}{l}\text { Overall, how satisfied were you with the grammar } \\
\text { video lessons? }\end{array}$ & 0 & 0 & 4 & 14 & 8 & 4 & 30 \\
\hline
\end{tabular}

Note: This table shows the students answers regarding the use of grammar video lessons.

The parameters considered for the survey were Strongly disagree (1), Disagree (2), Neither agree or disagree (3), Agree (4), and Strongly Agree (5). $70 \%$ of students agreed that using video lessons to introduce grammar content was an effective technique, $46 \%$ of students highly agreed on the usefulness of video lessons to learn grammar, and $42 \%$ agreed as well. 96\% of students considered that the content of the videos was excellent and the same percentage agreed that the image and audio were also high quality. $88 \%$ of students stated that video lessons were enough to understand and apply the grammar content, $81 \%$ considered that the WSQ chart was useful for understanding the grammar content in the video lessons. 96\% of students recommended the use of grammar video lessons in the English classroom, $88 \%$ of students were awarded of the high contribution of the video lessons in the 
development of activities in the class in an autonomous way. $85 \%$ of students concluded that overall they felt satisfied with the grammar video lessons used as a tool to develop independent learning cognitive skills.

\section{Discussion}

Even though, teachers are always innovating and finding new methods and strategies to motivate students to learn English, they do not really feel the need to speak a foreign language, $90 \%$ of students just take English classes because they are a requirement to graduate from the different careers. In general, students consider English one of the most difficult subjects to study; for that reason, it is predominant to give them reasons to learn and master this language. Students need to open their minds and expectations to the doors English can open for them not only in Ecuador, but also around the world. Some of the possibilities could be to study a Master's Degree, to be granted an international scholarship in the most recognized Universities around the world, read and understand books, and of course the experience of interacting with English speakers through social networks.

Too much has been told about the technology in the $21^{\text {st }}$ century; however, it could be complicated to introduce it in the classroom; nevertheless, as teachers we have to remember that technology transform the classroom experience from a classic teacher centered one into a student-centered experience with students taking a more active role in their learning. Some of the constraints teachers can face when inserting technology in the classroom were limited time, limited experimentation, and inefficient training for teachers. Despite the attraction technological activities add, planning the activities in the Virtual Classroom require extra time, the teacher has to administrate the classroom and choose the most effective activities to reach the main goal, which is motivating students to learn English. While technology keeps evolving, English teachers not always have the chance to stay updated about managing new technologies and the technical support they can receive at the work place is not always given in time. Since the main qualification of an English teacher is not mastering the use of new technologies, there are not too many possibilities to get effective training in the area of recording videos and manage Virtual Classrooms efficiently.

The first related study mentioned in the introduction of this paper used as independent variable audio podcast, which students had to record as homework (Han, 2015), on contrast 
to this study which used grammar video lessons that students had to watch. Both are similar in terms of measuring the effects to create independence in learning, which, in fact, was proved once student exhibited a high level of independence by doing the task voluntarily and repeatedly without any reserve at the end of both interventions. The second comparison is made between the article "Using the flipped classroom to enhance EFL learning" and the present study, both concentrated on improving independency to increase knowledge, however the former one focused on motivation which in fact proved to be a key point to create students' autonomy.

A lot has been said about the flipped classroom model, which in fact and based on evidence, is successful, nevertheless it is reasonable to discuss some findings on studies related to traditional classroom model (Kaye, 2008) specially to those, they state, cannot be reached with flipped classrooms. For instance, some studies point out that students working with flipped classrooms, do not create opportunities to engage in real communication, which is not always true, in fact, this study contradicts it because flipped classroom has to do with blended learning and since this study concentrated on watching the theoretical part at home, the real communication indeed happened in class. In addition, the environment flowed smoothly creating natural interaction with other learners.

Furthermore, Ali Tarhini Sultan from Qaboos University stated that other disadvantage of flipped classroom model might include "little or no "in-person" contact with the faculty member". Conversely, during the project intervention, the teacher was able to answer questions about what they did not understand, discuss in class the student's doubts and points of view and feedback from students' WSQ chart. This helped the teacher have more control over the aims, the pace and the materials. Other benefit of traditional classroom over the flipped classroom method is that provides students with fixed schedule and specific periods dedicated exclusively to learning (Paduraru, 2008) which can be true, since with flipped classrooms procrastination can become a common attitude while traditional classrooms preserve a feeling of "now and here" (Paduraru, 2008) Finally, learning about technology may be a drawback for flipped classrooms teachers who are not technologically native and this class approach can become time consuming adding more workload to thee teachers. However, since teachers do not, any longer, have to worry about some other problems such 
as mixed-abilities classrooms, late arrivals and misbehaviors as happens in on-site classrooms, the situation seems to get even. To sum up, every approach may present pros and cons, then it is necessary for teachers to analyze the population's features and evaluate which approach will suit the intervention.

\section{Conclusions}

- The data gathered in the initial survey results made it clear that there was a need to change the way the English classes were being developed to emphasize autonomous learning with activities outside the classroom, which not necessarily had to be homework.

- After developing the study, the researcher drew the following conclusions which are aligned with the objectives of this research. Since the students' grades improvement was high, it can be stated that the use of grammar video lessons and the flipped classroom model were effective in promoting autonomy in the learners. Innovating, changing, and blending the English classroom brought positive results in the students' performance not only because the researcher created the resources (Virtual Classroom and grammar video lessons on YouTube), but also because the time was planned more effectively and the theoretical in-time class was, in fact, reduced. Recording the videos, managing a Virtual Classroom and self-training were challenging tasks for the researcher, but the results were worth it.

- Students loved the idea of no homework and having time during the class to receive effective feedback from the teacher and work on more practical exercises with all the worksheets they were provided. They concluded saying that watching a video is more fun than sitting and listening since the more practice they get, the more confident they feel about the content. They said it is quite different to traditional classroom where they listen to the teacher and then, almost never, get the chance to practice what they learn in a real environment.

- It is also necessary to mention an interesting fact. Once students started using the grammar video lessons to learn grammar, they started to look for other videos or tutorials online to increase their possibilities and knowledge and even criticize or suggest variations to the videos created by the researcher. 
- Finally, the virtual class created for this purpose provided the guide they needed to use the grammar video lessons and the WSQ chart. Students felt motivated because they could read, re-read, watch and re-watch all the materials and they could do it at their own pace and wherever they were.

- In sum, the research hypothesis was accepted, the use of grammar video lessons fosters independent learners in ELF students.

\section{Referencias Bibliográficas}

Alpha Omega Academy. (12 de February de 2012). Alpha Omega Academy. Obtenido de https://www.aoacademy.com/7-characteristics-of-independent-learners/

Carl, H. (04 de Septiembre de 2016). Wellington Learning and Research Center. Obtenido de http://learning.wellingtoncollege.org.uk/what-do-we-mean-by-independentlearning/

Chen Hsieh, J. S.-C. (2016). Using the flipped classroom to enhance EFL learning. Computer Assisted LAnguage Learning, 1-21.

Ellis, A. K. (2004). Examplar of Curricular Theory p.33. Larchmont, NY: Eye on Education.

Hammond, Z. (2015). Culturally responsive teaching and the brain: Promoting authentic engagement. Corwin.

Han, Y. J. (Enero de 2015). NYS TESOL JOURNAL Vol. 2, No. 1. Obtenido de http://journal.nystesol.org/jan2015/Han_98-109_NYSTJ_Vol2Iss1_Jan2015.pdf

Harvey, V. S., \& Ckie-Wolfe, L. A. (2007). Fostering Independent Learning: Practical Strategies to Promote Student Success. London: The Guilford Press.

Hsieh, J. S., Wu, W.-C. V., \& Marek, M. W. (2016). Computer Assisted Language Learning. Obtenido de Using the flipped classroom to enhance EFL learning: https://www.tandfonline.com/action/showCitFormats?doi=10.1080\%2F09588221.2 015.1111910

Karen Murphy, P. A. (2016). Understanding how students learn: A guide for instructional leaders. California: Corwin Press.

Kaye, P. (2008). Teaching one to one. Obtenido de British Council: https://www.teachingenglish.org.uk/article/teaching-one-one

Lara, M. (8 de Septiembre de 2016). Fliped teaching method to improve high order thinking skills. Obtenido de Dspace.unach.edu.ec: 
http://dspace.unach.edu.ec/bitstream/51000/3084/1/UNACH-IPG-LIN-ING-20160008.pdf

Meyer, W. R. (2010). Independent learning: a literature review and a new project. British Educational Research Association Annual Conference, 35.

Nizar, M. (2015). Research Gate. Obtenido de https://www.researchgate.net/post/How_important_is_learner_autonomy

Nunan, D. (2002). Syllabus design. New York: Oxford University Press.

Paduraru, C. (08 de Marzo de 2008). The Advantages of Traditional Classroom Learning. Obtenido de https://classroom.synonym.com/advantages-traditional-classroomlearning-7964781.html

Sams, A., \& Bergmann, J. (2012). Flip your classroom. Colorado: International Society for Technology in Education.

Stephanie. (6 de January de 2018). Statistics How to. Obtenido de http://www.statisticshowto.com/probability-and-statistics/t-test/

Young, C. A. (2017). Applying the Flipped Classroom Model to English Language Arts Education. Hershey PA: IGI Global.

Zhen, H. (2014). Teacher beliefs as a complex system: Engglish Language Teachers in China. Chengdu, Singchua, Rp China: Springer . 


\section{PARA CITAR EL ARTÍCULO INDEXADO.}

Lara Freire, M., Escudero Orozco, G., Fuertes López, B., \& Rojas Yumisaca, W. (2019). Grammar video lessons to foster independent learners in the English as a foreign language classroom. Ciencia Digital, 3(3.1), 203-220. https://doi.org/10.33262/cienciadigital.v3i3.1.689

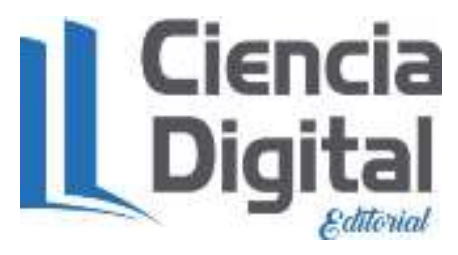

El artículo que se publica es de exclusiva responsabilidad de los autores y no necesariamente reflejan el pensamiento de la Revista Ciencia Digital.

El artículo queda en propiedad de la revista y, por tanto, su publicación parcial y/o total en otro medio tiene que ser autorizado por el director de la Revista Ciencia Digital.
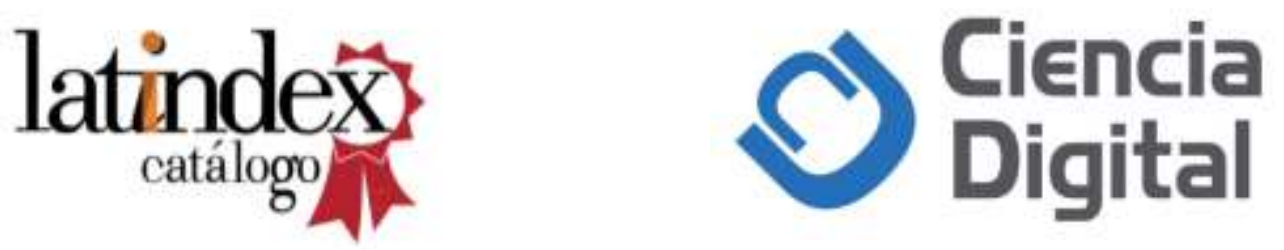